\title{
South Carolina: Republican Success, Democratic Decline
}

\author{
Laurence W. Moreland and Robert P. Steed
}

In 2004 South Carolina continued to play an increasingly familiar role: a critical battleground state in the presidential nomination process but a minor, generally ignored player in the general election.

South Carolina has become such a reliable source of eight electoral votes for Republican presidential candidates that the state no longer figures in presidential campaign strategies. Republican presidential candidates assume that the state will be a nearly fail-safe "red state" with little or no effort, and Democratic presidential candidates assume with a high degree of certainty that the state will once again be a Republican stronghold, regardless of what happens elsewhere. In the 2004 presidential election these assumptions quickly turned into hard facts early on in the election cycle. Indeed, beginning with the 1964 presidential election, Republican presidential candidates have carried the state in ten of the eleven presidential contests to date, with only 1976 standing as the lone exception (when Georgia neighbor Jimmy Carter carried the state).

South Carolina's move toward a dominant Republicanism has taken nearly half a century. The year 1964 was particularly important as it marked legendary Senator Strom Thurmond's shift to the Republican Party, making him only the second Republican senator in the South since Reconstruction (the first being John Tower who won Lyndon Johnson's seat in Texas in a special election in 1961); a few months later, not so coincidently, the state cast 59 percent of its vote for the 1964 Republican presidential candidate, Barry Goldwater, who thus became the first Republican to carry the state in a presidential election in the twentieth century.

In the period from 1964 into the 1980s, many of South Carolina's (white) voters cast their ballots for Republican candidates for president but Democratic candidates in other races. Even though Republican strength was regularly flexed in presidential races, the split-ticket voting habits of many white voters helped Democrats to retain majorities in the General Assembly as well as to retain most state-wide and local offices. The Republican "topdown" strategy, however, eventually proved successful, by promoting partisan dealignment of the white electorate and setting the stage for other

LAURENCE W. MORELAND is professor of political science at The Citadel.

ROBERT P. STEED is professor of political science at The Citadel.

The American Review of Politics, Vol. 26, Spring, 2005: 109-130

(C)2005 The American Review of Politics 
developments, mostly favorable to the Republicans, to move the state seemingly relentlessly toward making the Republican Party dominant in statewide elections, in the congressional delegation, and in the legislature. ${ }^{1}$ To be sure, the "top-down" strategy was aided by a succession of Republican state party chairs who worked tirelessly to build the party's organization so as to support down-ballot races (especially in the state's vote-rich urban-suburban areas) (see Steed 1997).

Even more important, though, were the changes taking place in the state's economic and social fabric and in white voter perceptions. In developments too complex to be detailed here, industrialization, suburbanization, the growth of the white middle class, the in-migration of middle class whites, and an influx of retirees to the state (typically Republican, especially those clustered around Hilton Head) all fueled Republican growth, especially in the urban-suburban corridors of the state clustered around GreenvilleSpartanburg, Columbia, and Charleston. In addition, white voter perceptions were changing significantly, influenced by the political mobilization of the Christian right, the proliferation of the view that Democratic nominees for the presidency were out of touch with South Carolina (a perception aided by the McGovern nomination in 1972 and the Dukakis nomination in 1988), and the popular presidency (in South Carolina) of Ronald Reagan who humanized and popularized the Republican Party (on this last point, see Black and Black 2002).

Consequently, by the turn of the 21st century, dealignment had turned into realignment, making the state as dependable a "red state" as any. To be sure, Democrats still retained overwhelming strength among AfricanAmerican voters and some strength in rural areas and in center cities (especially Columbia and Charleston), but overall the loss of most white voters was devastating, as (statewide) Democrats were seldom able to attract more than a quarter of the white vote. ${ }^{2}$

\section{The South Carolina Presidential Primary}

As we observed in our introduction to this series of articles, the South Carolina presidential primary is the first in the South, and, in general, it serves at least two functions beyond providing a relatively small number of delegates to a national nominating convention. First, it serves as a "gateway" to other southern primaries, giving some indication of how southern voters are reacting to various candidates. Second, it serves as something of a "firewall" after the first-in-the-nation New Hampshire primary. A candidate who does not do well in New Hampshire has a chance to reclaim at least some momentum by winning in South Carolina. Such was the case in 2000 when George W. Bush lost the New Hampshire primary to John McCain but 
managed to bounce back, and ultimately sweep the South, by winning the bitterly fought South Carolina primary. While there was no Republican contest in 2004, the Democratic primaries would in fact select the party's presidential candidate.

For Democratic presidential candidates in 2004, the Democratic primary was a high priority, and all visited the state at various times before the South Carolina presidential primary on February 3. Indeed, John Kerry kicked off his campaign in the state (Bandy 2003), and General Wesley Clark flew from announcing his candidacy in Arkansas to speak at The Citadel in Charleston. Moreover, a post-New Hampshire high-profile debate - featuring all remaining seven candidates for the nomination in a nationally televised joint appearance, moderated by NBC's Tom Brokawwas held in Greenville, South Carolina, in late January 2004 (Kropf and Scott 2004).

For John Edwards, after his distant fourth-place finish to Kerry in New Hampshire, the South Carolina primary was a "must-win" situation if he was to keep his candidacy alive. Edwards is a native of South Carolina, born in Seneca, and he lived in the state until he was ten. His family then moved to North Carolina, where he went to school and ultimately pursued a very successful legal career before entering politics there in 1998. With such a background, he hoped to score well in South Carolina, even to a large extent playing the role of native son. To help assure that he would at least survive the South Carolina primary, Edwards did not rely just on his friends-andneighbors credentials: he visited the state 27 times between January 2003 and the primary, he developed a formidable ground organization, he had useful endorsements (including Columbia Mayor Bob Coble and prominent African-American state senator Robert Ford), and he spent heavily on television advertising (Bauerlein 2004).

In the face of Edwards' all-out effort, two other candidates-Al Sharpton and Wesley Clark (both of whom visited the state often) - were likewise working to make a good showing, if not outright win the state. Reverend Sharpton, who did not have the money for television advertising but who hoped to make headway among the primary's expected large black turnout, pursued a strategy of visiting as many black churches as possible (and, in the process, he spent more time in the state than Edwards). General Clark hoped his stellar military credentials, his campaign themes of leadership and patriotism, and his southern roots (Arkansas) would be irresistible to South Carolina primary voters by combining Kerry's military background with Edward's southern origins.

The Kerry campaign, though, was something of an enigma. On the one hand, Kerry had appeared to take the state's primary seriously. For example, on October 2, 2002, Kerry had visited the state, appearing on Chris Mathews' 


\section{2 | Laurence W. Moreland and Robert P. Steed}

"Hardball" on cable television's MSNBC in a broadcast from The Citadel in Charleston. More importantly, Kerry visited Charleston again when he formally kicked off his campaign on September 2, 2003, on the deck of the USS Yorktown, a World War II aircraft carrier, now a museum permanently moored in Charleston harbor. In a dig at President Bush and as a reference to his own military service in the Navy, Kerry argued that, "Being flown to an aircraft carrier and saying, 'Mission Accomplished,' doesn't end war. And the swagger of a president saying 'Bring 'em on,' will never bring peace" (Bandy 2003, B1).

On the other hand, after his September announcement, Kerry spent just three days in the state, two of them just before the primary, January 29-30 (Bauerlein 2004, A10). And in other ways, too, it appeared that the Kerry campaign expected little in South Carolina: he had only seven full-time staffers (and four were reassigned to Iowa) and he bought little television time (Bauerlein 2004).

Thus it was that, despite polling which suggested that Edwards and Kerry would win about the same proportion of votes, South Carolina primary voters gave Senator Edwards 45.6 percent of their votes and his sole win in the 2004 Democratic primaries. Even with an absentee campaign, Senator Kerry won 29.7 percent, followed by Reverend Sharpton (9.4 percent), General Clark (7.2 percent), Governor Howard Dean (4.6 percent), Senator Joe Lieberman (2.5 percent), and U.S. Representative Dennis Kucinich (0.5 percent). Edwards' populist "two Americas" campaign theme appeared to appeal especially to voters in South Carolina's midlands, where unemployment was running much higher than the national average and where the industrial sector had been hemorrhaging jobs as much as anywhere in the nation (Broder 2004). Kerry's stronger-than-might-be-expected showing in the face of a low-level effort is likely at least partly due to late endorsements (quickly turned into Kerry television ads) from two of the state's few remaining powerhouse Democrats - retiring U.S. Senator Fritz Hollings and U.S. Representative Jim Clyburn, the state's only black member of Congress since Reconstruction. Of course, Kerry won five of the six non-southern primaries held on the same day, and less than six weeks later Kerry had enough delegates to assure the nomination. (For a recap of the 2004 Democratic presidential primaries, see the CNN-maintained website: http://www.cnn.com/ELECTION/2004/special/primary/.)

The South Carolina primary, while it did not this time prove to be a key victory for the ultimate winner, did advance Edwards as an important player in national politics, and, together with Edwards' southern background and populist appeal, it may have helped Kerry in his decision to select him as his vice presidential nominee. While the state's presidential primary did not play as significant a role as it has in previous years (for example, the 2000 
Republican presidential primary), it is likely to remain one of the handful of critical primaries. In anticipation of the 2008 contest for the presidency, nine potential Republican and Democratic candidates had already visited the state at least once in the first eight months of 2005 (Frank 2005).

\section{The Presidential Campaign in South Carolina}

As expected, South Carolina received little attention during the campaign. Certainly, neither candidate budgeted money for the state, and what television advertising South Carolina voters saw for either Bush or Kerry appeared on cable channels intended to reach targeted voters elsewhere. The state's Republican proclivity in presidential elections together with its meager eight electoral votes pretty much eliminated it as a target of interest for either campaign.

Despite formally opening his campaign in South Carolina, as noted above, Kerry was challenged five months later by Tom Brokaw in the nationally-televised primary debate in Greenville, when Brokaw accused Kerry of "kissing off the South." Although Kerry was said to have declared on another occasion that he could win the election without carrying a single southern state, Kerry denied the charge, arguing that, "I have always said I'll compete in the South. I have always said I can win in the South. I think the person who needs to worry is George Bush" (Kropf and Scott 2004, 12A). As this series of articles demonstrates, it is very doubtful if there was ever much worry in the Bush campaign, and certainly they were not worried about South Carolina.

Despite the state's very low priority for both tickets, one national candidate did visit the state after Labor Day. John Edwards had promised earlier in the year that he would return to the state during the campaign. He kept that promise on September 22, speaking at a rally and then a fundraiser in Columbia. Since the race was a difficult one for the Democrats and in late September the ticket was running behind Bush-Cheney in the national polls (and even some states won by Al Gore appeared to be shaky), many expected Edwards to forget the promise. State Democrats were consequently quite gratified by the visit (Barbour 2004a).

\section{Analysis: The Presidential Race Results in South Carolina}

\section{Turnout}

When compared with other states, South Carolina once again ranked near the bottom in terms of turnout in the 2004 general election. Based on voting as a percentage of the voting-eligible population, South Carolina 
ranked 50th (of 50 states plus the District of Columbia) at 52.5 percent (U.S. Elections Project 2005). (For the nation as a whole, 59.0 percent of eligible voters turned out at the polls; see McDonald 2004a.). However, if turnout is based on voting as a percentage of the voting-age population, South Carolina ranks somewhat higher, 42nd (of 51), at 50.7 percent (U.S. Elections Project 2005). While South Carolina typically ranks low in voter turnout, the 2004 election general election in the state lacked at least two factors-"battleground" status plus a gay-marriage ballot issue-which appear to have improved voter turnout elsewhere (McDonald 2004b). Even so, the election did feature a U.S. Senate election which was vigorously contested and which was expected to be highly competitive, a factor which elsewhere also seemed to have been related to higher voter turnout (McDonald 2004).

\section{Results}

On November 2, as predicted by all polling in the state throughout the summer and fall, President Bush easily won South Carolina with 58.0 percent of the vote, improving by 1.2 percent over his 2000 percentage (56.8 percent) (Table 1). John Kerry's 40.9 percent equaled Al Gore's percentage in 2000, but he did not win as large a proportion of the vote as Bill Clinton did in 1996 (44.0 percent), even though Clinton was regularly drubbed in the state's newspapers and on local talk radio (see Moreland and Steed 2002). For the seventh consecutive presidential election (and for the ninth time out of the last ten elections), Republicans won South Carolina's eight electoral votes.

\section{Geography}

Republican strength in the state has centered on the state's urban/ suburban corridors, which include 15 of the state's 46 counties and which are located in three broad geographic areas of the state (lowcountry, midlands, and upstate). Aggregately, they contributed 70 percent of the statewide presidential vote in 2004. President Bush carried all three urban corridors by very substantial margins, winning 57.3 percent in the lowcountry, 55.8 percent in the midlands, and a whopping 66.2 in the upstate (a region which alone contributed a little over a quarter of statewide votes) (Table 2). Of the 15 urban/suburban counties, Bush carried 13, losing only in Richland County and in neighboring Sumter County (where he lost by only a little over 600 votes out of about 37,000 cast in that county). Despite Republican successes elsewhere, populous Richland County (only Greenville County in the upstate has more registered voters) has remained a Democratic stronghold, explained by its high proportion of government workers (the county 
includes the state capital, Columbia), a large non-white population (43.7 percent of those voting in the 2004 general election in Richland County were non-white), and the presence of the state's largest university, the University of South Carolina.

The strength of the Republican Party in the three urban/suburban corridors has been apparent now for at least twenty years. In 1988, for example, George H.W. Bush carried all three corridors by an average of 65.1 percent (Moreland, Steed, and Baker 1991, 131), compared with his son's average of 59.3 percent in 2000 (Moreland and Steed 2002, 119) and 60.3 percent in 2004 (see Table 2). What is new, though, is increasing Republican strength in the mostly rural 31 counties which fall outside the urban/suburban corridors. Bill Clinton won 22 of these counties in both 1992 and 1996. But Al Gore won only 14 of them in 2000, and John Kerry won only 13 in 2004. Aside from Richland County (and occasionally, Sumter), Democrats are increasingly able to carry only those small rural counties where non-whites make up at least 45 percent of the registered voters.

\section{Race, Gender, Age, and Income}

Race continues to be a defining factor in South Carolina politics. Nonwhites (mostly African Americans) have come to constitute the base of the Democratic Party as very nearly the party's only reliable large-scale demographic group. Conversely, whites have become the base of the Republican Party. In 2004, Bush won nearly 80 percent of the white vote in South Carolina, which has become a typical proportion of the white vote that Republicans have been able to win in statewide elections (National Election Pool 2004) (Table 3). In a state where nearly 72 percent of the registered voters are white (with a little over 28 percent non-white), the Democrats thus have a daunting task in winning statewide elections as, at a minimum, they must attract the votes of about 35 percent of the white electorate, a goal they rarely reach. On the other hand, in 2004 the Kerry-Edwards ticket won 85 percent of the African-American vote.

South Carolina voters continue to exhibit a gender gap, as they did in the 1996 and 2000 presidential elections (Moreland and Steed 1997; Moreland and Steed 2002). In the 2004 presidential election, while a majority of both men and women overall supported the Republican ticket, women were more closely divided ( 63 percent of men for Bush and 55 percent of women for Bush). However, the gender gap actually occurred only among non-white voters. Among whites, Bush received exactly the same level of support (an overwhelming 78 percent) from both men and women. Among non-whites (mostly African American in South Carolina), while Kerry won big majorities among both men ( 74 percent) and women ( 83 percent), Bush did 
Table 3. Demographic Characteristics of the 2004 South Carolina Presidential Vote, by Candidate (in percent)

\begin{tabular}{|c|c|c|c|}
\hline Characteristic & Bush & Kerry & Percent of Category \\
\hline \multicolumn{4}{|l|}{ Race } \\
\hline White & 78 & 22 & 67 \\
\hline African American & 15 & 85 & 30 \\
\hline Other & $*$ & $*$ & $*$ \\
\hline \multicolumn{4}{|l|}{ Gender } \\
\hline Male & 63 & 36 & 43 \\
\hline Female & 55 & 45 & 57 \\
\hline \multicolumn{4}{|l|}{ Race and Gender } \\
\hline White men & 78 & 22 & 31 \\
\hline White women & 78 & 22 & 36 \\
\hline Non-white men & 25 & 74 & 12 \\
\hline Non-white women & 17 & 83 & 21 \\
\hline \multicolumn{4}{|l|}{ Age } \\
\hline $18-29$ & 51 & 48 & 18 \\
\hline $30-44$ & 58 & 41 & 29 \\
\hline $45-59$ & 60 & 39 & 33 \\
\hline 60 and older & 61 & 39 & 20 \\
\hline \multicolumn{4}{|l|}{ Income } \\
\hline Under $\$ 15,000$ & 38 & 61 & 8 \\
\hline$\$ 15-30,000$ & 47 & 53 & 16 \\
\hline$\$ 30-50,000$ & 56 & 43 & 23 \\
\hline$\$ 50-75,000$ & 63 & 36 & 25 \\
\hline$\$ 75-100,000$ & 70 & 30 & 13 \\
\hline$\$ 100-150,000$ & 68 & 31 & 8 \\
\hline$\$ 150-200,000$ & 65 & 33 & 3 \\
\hline$\$ 200,000$ or more & $*$ & $*$ & 3 \\
\hline \multicolumn{4}{|c|}{$\begin{array}{l}\text { *Sample size too small to be significant. } \\
\text { Note: Candidate percentages may not add to } 100 \text { as the Nader percentages (generally } 1 \text { percent or } \\
\text { less) have been omitted. } \\
\text { Source: National Election Pool } 2004 \text { South Carolina exit poll. }\end{array}$} \\
\hline
\end{tabular}

somewhat better among non-white men. In addition, the impact of this gender gap is magnified by the fact that non-white women constituted a larger proportion of those actually voting ( 21 percent) than the proportion of non-white men voting (12 percent). It is fair to conclude that AfricanAmerican women have become the biggest and most reliable constituency for the Democratic Party in South Carolina (as well as much, if not all, of the South). 
President Bush carried almost all age and income groups in South Carolina. A majority of all age groups supported him, with his biggest margins coming from those 45 and older. Among those in the 18-29 age group, Bush and Kerry came close to splitting the group evenly (51 percent for Bush, 48 percent for Kerry). As usual, though, this youngest age group constituted a small proportion of those voting (18 percent) (Table 3). Among the income groupings in the NEP exit polling, Bush won a majority of the votes of those earning more that $\$ 30,000$ per year. Of course, race and income overlap significantly, since African Americans are disproportionately represented among those earning under $\$ 30,000$.

\section{Religion}

South Carolina, mostly Protestant, is a state where the Christian right has been become a formidable political presence. While organizationally not as strong as in the 1980s and 1990s when Pat Robertson led the Christian Coalition, the Christian right's issues resonate among a large proportion of the state's voters. Bush did nearly as well among Catholics as among Protestants (65 to 62 percent), and he won by huge margins among those who described themselves as "white conservative Protestants" (winning 96 percent of their vote) and/or as "white evangelical/born-again" (winning 88 percent) (Table 4). Only among those who indicated "other" or no religion as their religious preference did Kerry score well, winning both of these groups (64 percent and 76 percent, respectively); of course, together they constituted only a small fraction of the 2004 South Carolina electorate (14 percent).

\section{Party Identification and Ideology}

A third of the voters in South Carolina identified themselves as Democrats, a proportion just barely higher than the proportion of African-Americans in the electorate (Table 4). Edging toward half of the electorate, 44 percent identified themselves as Republicans, with the remainder ( 23 percent) self-identifying as independents. While Bush won nearly all of those who are Republicans (96 percent) and Kerry won almost as high a percentage among Democrats (92 percent), Bush easily carried a substantial majority of those who are independents ( 56 percent to Kerry's 42 percent).

Similarly, those who identified themselves as conservative (39 percent of those voting) very heavily supported Bush (at 83 percent) while the small minority of those describing themselves as liberal (15 percent) strongly supported Kerry (at 76 percent), although Bush did better among conservatives than Kerry did among liberals. Moderates, the largest segment of the 
Table 4. Religious, Party Orientation, and Ideological Characteristics of the 2004 South Carolina Presidential Vote, by Candidate (in percent)

\begin{tabular}{lccc}
\hline Characteristic & Bush & Kerry & Percent of Category \\
\hline White Conservative Protestant? & & & \\
$\quad$ Yes & 96 & 4 & 24 \\
$\quad$ No & 47 & 52 & 76 \\
White Evangelical/Born-Again? & & & \\
$\quad$ Yes & 88 & 11 & 30 \\
$\quad$ No & 46 & 53 & 70 \\
Religious Denomination & & & \\
$\quad$ Protestant & 65 & 35 & 75 \\
$\quad$ Catholic & 62 & 37 & 10 \\
Jewish & $*$ & $*$ & 1 \\
$\quad$ Other & 34 & 64 & 8 \\
$\quad$ None & 23 & 76 & 6 \\
Party Identification & & & \\
$\quad$ Republican & 96 & 3 & 44 \\
$\quad$ Democrat & 8 & 92 & 33 \\
$\quad$ Independent & 56 & 42 & 23 \\
Ideology & & & \\
$\quad$ Conservative & 83 & 16 & 39 \\
$\quad$ Moderate & 49 & 50 & 46 \\
$\quad$ Liberal & 24 & 76 & 15 \\
*Sample size too small to be significant. & & & \\
Note: Candidate percentages may not add to 100 as the Nader percentages (generally 1 percent or \\
less) have been omitted. \\
Source: National Election Pool 2004 South Carolina exit poll. \\
\hline
\end{tabular}

electorate in ideological terms (at 46 percent), split virtually down the middle: 49 percent for Bush and 50 percent for Kerry. That Kerry did relatively well among this group can only be explained by the assumption that many African-American voters described themselves as moderates.

\section{Issues}

President Bush has been extremely popular in South Carolina (he has visited the state numerous times, particularly in the 2000 election cycle), and his popularity is without a doubt a reflection of the state's religious, economic, and social conservatism and affinity for the military (including a strong 
tendency, as elsewhere, to rally around the nation's leader during wartime). According to the NEP exit polling in the state, the top four issues in 2004 were moral values (the "most important" issue for 23 percent of those voting), terrorism (23 percent), economy/jobs (17 percent), and Iraq (15 percent), aggregately accounting for 78 percent of the electorate) (Table 5).

President Bush was overwhelmingly favored by those who saw moral values and terrorism as the "most important" issue in the election, two issues which together accounted for nearly half ( 46 percent) of the electorate; Bush won 88 percent of the votes of the morals values voters and 86 percent of the terrorism voters. While Kerry was favored by those who saw the remaining two issues as most important (economy/jobs and Iraq), he did not win as decisively as Bush had on moral values and terrorism (Kerry won 79 percent of those who thought the economy/jobs was the most important issue and 67 percent of those indicating Iraq as the most important issue). Moreover, Kerry's two winning issues were the most important issue for only about a third of the electorate. That the economy/jobs issue did not resonate more widely among voters may be somewhat surprising. South Carolina has an economy in which a large segment is based on manufacturing, and that segment has been hit hard in recent years by foreign competition (the textile industry, for example, is only a shadow of what it once was). Moreover, in October 2004 the state's unemployment rate was one of the highest in the country, at 6.5 percent (the national unemployment rate was 5.5 percent) (South Carolina Employment Security Commission 2004). Even so, the state of the economy was the "most important issue" for less than a fifth of the voters.

When asked about the "most important quality" sought in a new president, South Carolina voters strongly tended to give their votes to Bush when qualities such as a strong leader (90 percent for Bush), a clear stand on issues (73 percent), religious faith (91 percent), and honesty/trustworthiness (78 percent) were the qualities that were important to them. Kerry scored well among those voters who sought a leader who will bring change (93 percent for Kerry), who cares about people (65 percent), or who is intelligent (83 percent) were the qualities that were important to them. Aggregately, Bush had a clear advantage as 60 percent of the electorate chose the four qualities on which Bush scored extremely well (Table 5).

Finally, South Carolina voters were willing to give Bush high marks in terms of overall job approval, trust in handling terrorism, and the decision to go to war in Iraq. Under these circumstances, against an incumbent president in the post-9/11 political climate, it is not surprising that the Kerry-Edwards ticket failed to generate much excitement or that the ticket did not actively contest a state with the political and social characteristics of South Carolina. 
Table 5. Voter Attitudes in the 2004 South Carolina Presidential Vote, by Candidate (in percent)

\begin{tabular}{|c|c|c|c|}
\hline Attitude & Bush & Kerry & Percent of Category \\
\hline \multicolumn{4}{|c|}{ Your Vote for President Was Mostly- } \\
\hline For your candidate & 66 & 34 & 72 \\
\hline Against his opponent & 39 & 59 & 24 \\
\hline \multicolumn{4}{|c|}{ How Bush Is Handling His Job } \\
\hline Approve & 92 & 8 & 59 \\
\hline Disapprove & 9 & 89 & 40 \\
\hline \multicolumn{4}{|c|}{ Trust Kerry to Handle Terrorism } \\
\hline Yes & 12 & 87 & 34 \\
\hline No & 86 & 14 & 59 \\
\hline \multicolumn{4}{|c|}{ Trust Bush to Handle Terrorism } \\
\hline Yes & 86 & 13 & 61 \\
\hline No & 8 & 91 & 33 \\
\hline \multicolumn{4}{|c|}{ Decision to Go to War in Iraq } \\
\hline Approve & 89 & 11 & 56 \\
\hline Disapprove & 15 & 84 & 38 \\
\hline \multicolumn{4}{|l|}{ Most Important Issue } \\
\hline Moral values & 88 & 12 & 23 \\
\hline Terrorism & 86 & 13 & 23 \\
\hline Economy/jobs & 20 & 79 & 17 \\
\hline Iraq & 33 & 67 & 15 \\
\hline Taxes & 69 & 30 & 5 \\
\hline Education & 39 & 60 & 4 \\
\hline Health care & 17 & 80 & 4 \\
\hline \multicolumn{4}{|l|}{ Most Important Quality } \\
\hline Strong leader & 90 & 9 & 21 \\
\hline Will bring change & 6 & 93 & 19 \\
\hline Clear stand on issues & 73 & 26 & 14 \\
\hline Religious faith & 91 & 9 & 13 \\
\hline Honest/trustworthy & 78 & 22 & 12 \\
\hline Cares about people & 34 & 65 & 10 \\
\hline Intelligent & 16 & 83 & 5 \\
\hline \multicolumn{4}{|c|}{ Family's Financial Situation } \\
\hline Better & 84 & 16 & 36 \\
\hline Same & 58 & 41 & 38 \\
\hline Worse & 24 & 75 & 25 \\
\hline \multicolumn{4}{|c|}{$\begin{array}{l}\text { Note: Candidate percentages may not add to } 100 \text { as the Nader percentages (generally } 1 \text { percent } \\
\text { less) have been omitted. } \\
\text { Source: National Election Pool } 2004 \text { South Carolina exit poll. }\end{array}$} \\
\hline
\end{tabular}




\section{Analysis: U.S. Senate, U.S. House of Representatives, South Carolina General Assembly}

South Carolina elects nine state-wide constitutional officers (governor, lieutenant governor, etc.) every four years; however, those elections are not held during presidential years but during the off-year election cycle. In the last state-wide election cycle, in 2002, Republicans had won the governorship (as well as six of the other eight constitutional offices), had won an open U.S. Senate seat, and had taken full control of the General Assembly by winning the state Senate for the first time since the Civil War era (see Steed and Moreland 2006; see also n. 1). Although in 2002 Democrats won only two of the nine state constitutional officers (state treasurer and state superintendent of education), they nevertheless went into the 2004 election with considerable hope, especially for retaining the U.S. Senate seat being vacated by retiring Democratic Senator Fritz Hollings.

\section{U.S. Senate Race}

Although Senator Hollings had indicated in August of 2000 that he planned to run for a seventh term in 2004 (Bandy 2000), the 81-year-old senator subsequently changed his mind (Sheinin 2003). With the Hollings retirement, Republicans both locally and nationally saw the seat as one rightfully theirs, given the long-term Republican trend in South Carolina. Consequently, the Republican senatorial nominating primary was highly competitive, and it featured four major candidates, including a former governor (David Beasley), the state's attorney general (Charlie Condon), a three-term U.S. Representative (Jim DeMint of the state's Fourth District centered on Greenville-Spartanburg), and a successful businessman with a well-known name (Thomas Ravenel, who invested nearly $\$ 3$ million of his own money in his campaign and who is a son of Arthur Ravenel, one of the state's best known and most prominent early Republicans who had served in both the state legislature and in Congress). Tracking polls showed Beasley in the lead with the others struggling to come in second in the June 8 primary in the expectation that a run-off would be required to select a nominee (Sheinin 2004). Beasley did indeed come in first with 37 percent of the vote but was far short of the 50 percent necessary to win outright, and DeMint (with 26 percent) won the other spot in the runoff primary scheduled for two weeks later. In the runoff, DeMint tagged Beasley as a "flip-flopper" and attacked his protectionist policies on trade. DeMint also picked up the endorsements of the two other principal candidates in the first primary (Condon and Ravenel) as well as the endorsement of the only South Carolina daily newspaper with state-wide distribution (The State newspaper, published in Columbia) 
(Holland 2004). In the June 22 runoff, DeMint easily beat Beasley with over 59 percent of the vote.

Democrats avoided an expensive (and perhaps divisive) primary when Columbia mayor Bob Coble withdrew from the race, leaving the way open for Inez Tenenbaum who, as state superintendent of education, was one of the two Democrats holding statewide office (the other was Grady Patterson, the state treasurer, who has served in that post for almost three decades). Tenenbaum was an articulate and vigorous campaigner, and she was expected to be about as strong a candidate as the Democrats could realistically field. On the other hand, South Carolina has not been a very hospitable venue for female candidates for public office, especially beyond the county level; South Carolina, for example, ranks dead last among the 50 states in percentage of women in the state legislature, with just 8.8 percent of the 170 members of the General Assembly being female, as compared with a national average of 22.5 percent (National Conference of State Legislatures 2005).

Together, DeMint and Tenenbaum fought the costliest political race in South Carolina history, together spending over $\$ 15$ million on the campaign (Table 6). DeMint spent a little over $\$ 9$ million, and Tenenbaum, $\$ 6.2$ million; however, DeMint spent well over $\$ 3$ million to win the Republican nomination while Tenenbaum had only token opposition in the Democratic nominating primary (see Markoe 2004). With five Senate seats in the South being vacated by incumbent Democrats in 2004 (the other four states were North Carolina, Florida, Louisiana, and Georgia), national Democrats hoped that South Carolina might present a good chance to retain one of these seats; consequently, the Democratic Senatorial Campaign Committee invested heavily in the race, sending nearly $\$ 1$ million to the South Carolina Democratic Party (Center for Responsive Politics 2005).

In the campaign, DeMint was aided by outside " 527 " groups, especially the anti-tax Club for Growth, which very early on ran television advertisements which sought to define Tenenbaum as a failed educational bureaucrat and profligate spender. In its press releases the state GOP routinely labeled Tenenbaum as an "ultra liberal." DeMint himself took every opportunity to link Tenenbaum to Democrats such as Ted Kennedy and Bill and Hillary Clinton who are generally unpopular in the state. In a joint appearance on NBC's "Meet the Press" in October, for example, DeMint noted that Tenenbaum had supported Bill Clinton and Al Gore and was supporting John Kerry in 2004: "You have been a rubber stamp" (Barbour 2004). DeMint did falter a bit when he suggested that gays, lesbians, and unmarried pregnant women should not be permitted to be teachers in public schools, opinions for which he later offered something of an apology (see Kropf 2004c). 
Table 6. Results of 2004 Senatorial Election in South Carolina

\begin{tabular}{lccc}
\hline Election & $\begin{array}{l}\text { Percent } \\
\text { of Vote }\end{array}$ & Votes Cast* & $\begin{array}{c}\text { Campaign Expenditures } \\
\text { 2003-2004 }\end{array}$ \\
\hline Jim DeMint (R) & 53.7 & 857,167 & $\$ 9,041,777.00$ \\
Inez Tenenbaum (D) & 44.1 & 704,384 & $\$ 6,265,786.00$ \\
Minor party candidates** & 2.2 & 35,670 & na \\
*Write-in votes have been excluded. & & \\
**Five minor parties ran candidates for the U.S. Senate seat. Only one submitted a financial report \\
(indicating an expenditure of $\$ 13,318)$. \\
Sources: Voting data compiled by the authors from official returns from the South Carolina State \\
Election Commission (accessed at www.state.sc.us/cgi-bin/scsec/r1). Campaign expenditure data \\
from The Center for Responsive Politics (accessed at www.opensecrets.org/races/summary.asp?id= \\
SCS1\&cycle=2004).
\end{tabular}

Although her campaign did seem to flounder over the summer, Tenenbaum found an issue during the last six weeks of the campaign which she hoped would sour voters on DeMint, namely DeMint's support of a bill that would replace the federal graduated income tax with a national sales tax. Tenenbaum seemed to gain some traction with her claim that DeMint's plan would add a 23 percent sales tax on all purchases, including new homes, food, prescription drugs, and all other purchases. Like DeMint, Tenenbaum was the beneficiary of television advertisements run by groups from outside the state, particularly on this issue.

In the 2004 general election, DeMint easily beat Tenenbaum (53.7 to 44.1 percent) in a race that had been expected to be close (the Cook Political Report had rated the race a tossup in July) although polling a month before the election indicated DeMint had established a substantial lead (Kropf 2004) (Table 6). With nearly a 10 percent margin of victory, Republican DeMint claimed a Senate seat that had theretofore been in Democratic hands since Reconstruction.

In a state which has been trending Republican and in a political environment where the Republican presidential nominee was a certain winner, in hindsight it is doubtful that Tenenbaum could have won, no matter how hard she campaigned or how well crafted her campaign might have been. Tenenbaum was an attractive, highly-motivated, and energetic candidate and she ran a well-funded campaign; nevertheless, she ran only a little more than 3 percentage points better than Kerry, who conducted no campaign at all in the state.

Although Tenenbaum had hoped that female voters would welcome her candidacy as an opportunity to place a woman in a highly visible elective position (and both parties targeted women; see Talhelm 2004), NEP exit 
polling indicated that DeMint and Tenenbaum evenly split the vote among women. While Tenenbaum did do better than Kerry among men, she still lost the male vote by 39 percent to 60 percent. In most ways, the vote followed the same patterns as the presidential vote: DeMint won almost all demographic groups (as measured by exit polling) with Tenenbaum winning substantial majorities only among African Americans, liberals, Democrats, and voters earning under $\$ 30,000$. While NEP polling indicated that she did win narrowly in a few other demographic categories (voters aged 18 to 29, for example), the overall picture was one highly disappointing to Democrats, since ultimately the vote count was not even close. While Democrats hoped that Tenenbaum would continue to be a prominent figure in state politics, given the dearth of Democrats with statewide name recognition or election experience, Tenenbaum in 2005 announced that she would not be a candidate for reelection as state superintendent of education.

\section{U.S. House of Representatives}

Of South Carolina's six House seats, five were defended by incumbents. South Carolinians have long had a tendency to keep incumbents in office, particularly in Congress (and the state has long profited from the resulting seniority). None of the incumbents faced a serious challenge, and all five were easily reelected, by percentages ranging from 63 to 100 percent (Table 7). The remaining seat-in the Fourth Congressional District, centered on Greenville-Spartanburg - was an open seat, having been vacated by Jim DeMint for his successful run for the Senate. But even there, a kind of quasi-incumbency was at work, as the seat was won by Bob Inglis, who had held the seat for three terms in the 1990s, vacating it in 1998 for an unsuccessful run for the U.S. Senate against Senator Hollings.

\section{South Carolina General Assembly}

Echoing the national picture, in 1994 Republicans had won control of the House of Representatives in the Republican sweep of that year, becoming the first legislative chamber in the South (along with the lower house of the Florida legislature) to come under Republican control. Quite similarly, Republicans had evenly split the Senate with Democrats in 2000 (just as with the U.S. Senate that year), although the tie was soon broken in South Carolina when a newly-reelected Democrat switched to the Republican side of aisle, giving the Republicans outright control (Moreland and Steed 2002).

Election year 2004 was not a key year for the South Carolina General Assembly. While all 124 seats in the House of Representatives and all 46 in the Senate were on the ballot, there was little overall change in the partisan 
Table 7. Results of the 2004 U.S. House of Representatives Elections in South Carolina

\begin{tabular}{|c|c|c|c|}
\hline Congressional District & Percent & Votes & Amount Raised \\
\hline \multicolumn{4}{|l|}{ First District } \\
\hline Henry Brown, incumbent (R) & 87.9 & 186,448 & $\$ 488,256$ \\
\hline James E. Dunn (Green) & 12.1 & 25,674 & 0 \\
\hline \multicolumn{4}{|l|}{ Second District } \\
\hline Joe Wilson, incumbent (R) & 65.1 & 181,862 & $\$ 891,295$ \\
\hline Michael R. Ellisor (D) & 33.4 & 93,249 & 12,980 \\
\hline Steve Lefemine (Constitution) & 1.6 & 4,447 & 150 \\
\hline \multicolumn{4}{|l|}{ Third District } \\
\hline J. Gresham Barrett & 100.0 & 191,052 & $\$ 724,210$ \\
\hline \multicolumn{4}{|l|}{ Fourth District } \\
\hline Bob Inglis, incumbent (R) & 69.8 & 188,795 & $\$ 504,492$ \\
\hline Brandon P. Brown (D) & 29.0 & 78,376 & 15,867 \\
\hline C. Faye Walters (Green) & 1.2 & 3,273 & 0 \\
\hline \multicolumn{4}{|l|}{ Fifth District } \\
\hline John Spratt, incumbent (D) & 63.1 & 152,867 & $\$ 830,981$ \\
\hline Albert F. Spencer (R) & 36.9 & 89,568 & 1,211 \\
\hline \multicolumn{4}{|l|}{ Sixth District } \\
\hline James (Jim) Clyburn, incumbent (D) & 67.1 & 161,987 & $\$ 692,448$ \\
\hline Gary McLeod (R and Constitution) & 32.9 & 79,600 & 8,542 \\
\hline \multicolumn{4}{|c|}{$\begin{array}{l}\text { Sources: Voter data compiled by the authors from official returns from the South Carolina State } \\
\text { Election Commission (accessed at www.state.sc.us/cgi-bin/scsec/r1). Campaign funds raised dat } \\
\text { from the Center for Responsive Politics (accessed at www.opensecrets.org/states/election.asp?State= } \\
\text { SC\&year }=2004) \text {. }\end{array}$} \\
\hline
\end{tabular}

division. In the 2004 elections, with very few seats seriously contested, Republicans retained control of both houses, holding the Senate by a 26-20 margin (a gain of 1) and the House of Representatives by a 74-50 margin (also a gain of 1 ).

\section{Conclusion: The Future of South Carolina Politics}

The 2004 elections confirmed and consolidated Republican dominance in statewide elections in South Carolina. For the seventh consecutive time, the Republican presidential candidate (easily) won the state's eight electoral votes.

For the first time ever, Republicans claimed both U.S. Senate seats. With Lindsey Graham taking Strom Thurmond's seat in 2002 and Jim 
DeMint winning Fritz Hollings' seat in 2004, the state's Senate delegation jumped several generations forward, as Thurmond and Hollings had served together for thirty-six years (Thurmond was first elected in 1954 and Hollings in 1966). Both Graham and, especially, DeMint are conservatives. Both have voting records highly supportive of the Bush administration and its policies, although Graham (a House Manager in the Bill Clinton impeachment trial) has, at times been somewhat surprisingly outspoken, even independent. He is, for example, a member of the "gang of 14," that is, one of the seven Republicans and seven Democrats in the Senate who engineered a compromise on filibusters of judicial nominations forwarded to the Senate by the President (for which Graham received harsh criticism from some South Carolina Republicans, but also praise from some quarters; see Rainey 2005), and he has been critical of the conduct of the Iraq War. DeMint is likely to continue to be the relentlessly pro-business, social conservative that he was during his three terms in the U.S. House of Representatives. Indeed, in his first months as a senator, DeMint has gamely pushed measuressocial security reform (personal accounts) and tax reform-that have not resonated well with many fellow Republicans in the Senate, much less the general public.

The state's Republican governor, former First District Congressman Mark Sanford, is expected to run for reelection in 2006 as the Democrats struggle to find a viable candidate. Many in the state believe Sanford has presidential ambitions for 2008, to date only modestly disguised (Bandy 2005a; Bandy 2005b). However, Sanford, who often tends to be more libertarian than conservative, had had his problems with the Republicancontrolled state legislature, and his sometimes aloof style has resulted in little in the way of accomplishment of major initiatives, something he must remedy if he is to make a presidential run.

The state's delegation to the U.S. House of Representatives continues to be split 4-2 in favor of the Republicans, as it has been since 1994. However, Republicans fully expect to pick up the Fifth District seat long held by Democrat John Spratt (first elected in 1982), once he vacates it. Democrats will hang on to at least one seat, however, as they are probably a lock to hold the majority-minority Sixth District seat, currently held by Jim Clyburn.

South Carolina Democrats were truly stunned by the magnitude of Inez Tenenbaum's defeat in the 2004 Senate race, as she had more-than-adequate financing, she was a smart and articulate candidate, and she had shown statewide vote-getting ability (when she was reelected state superintendent of education in 2002, she won more votes than any candidate for any office in South Carolina history). Her loss sharply pointed up the problems faced by the state's Democrats. While the Republican Party is not likely to dominate the state in the overwhelming fashion that the Democrats had done in the 
first half of the twentieth century, they are nevertheless now the normal majority party. Democrats will likely retain a visible, vocal, and sizeable minority in the state legislature, but to win stateside elections in the foreseeable future they must look to special circumstances. Democrats are now dependent on a confluence of highly favorable short-term political factors to win statewide elections - such as fielding an especially attractive candidate, exploiting Republican mistakes or poor Republican candidates, finding and harnessing an issue that has special resonance with the electorate, or some combination of these. The last several election cycles have shown that Democrats, absent these special circumstances, find it difficult to poll more than 41-45 percent of the vote.

At this point, the southern political realignment long predicted and much studied has now reached maturity, at least in South Carolina. Only new rounds of significant social, political, and economic changes of the sort experienced by the South over the last half century are likely to alter the South Carolina political equation.

\section{NOTES}

\footnotetext{
${ }^{1}$ The principal setback - and one that caused some to wonder if the Democrats had finally stopped, even reversed, the hemorrhaging - came in the 1998 election cycle, when Democrat Jim Hodges, combining two popular issues in the form of an "education lottery," managed to unseat a Republican governor (David Beasley) who had made a series of missteps; in that same election then-76-year-old Democratic Senator Ernest ("Fritz") F. Hollings won reelection to a sixth full term (see Moreland and Steed 2002). However, things seemingly returned to the Republican version of normal in 2000 and 2002. In 2000, George W. Bush easily carried the state (with almost 57 percent of the vote). In 2002, Republican Mark Sanford won 53 percent of the vote in defeating incumbent Democratic Governor Hodges, and the open U.S. Senate seat (finally vacated by the legendary 100-year-old Strom Thurmond) was won by Republican U.S. Representative Lindsey Graham who defeated Democrat Alex Sanders, a former chief judge of the state Court of Appeals and a former president of the College of Charleston. Also in 2002, the Republicans took control of the state Senate, having already controlled the lower house of the General Assembly since 1994 (see Steed and Moreland 2006).

${ }^{2}$ The brief summary of changes in South Carolina politics in this section is drawn from a series of publications where we have explored political and other developments in the state, sometimes in considerable detail, over the last several decades; see Steed and Moreland 2006; Steed and Moreland 2003; Moreland and Steed 2002; Steed and Moreland 1999; Steed 1997; Moreland and Steed 1997; Steed, Moreland, and Baker 1995a; Steed, Moreland, and Baker 1995b; Moreland 1994; Steed, Moreland, and Baker 1992; Moreland, Steed, and Baker 1991; Moreland, Steed, and Baker 1986.
} 


\section{REFERENCES}

Bandy, Lee. 2000. Hollings Says He'll Run for Seventh Term in 2004. Columbia The State, August 15.

Bandy, Lee. 2003. Kerry Kicks Off Campaign for President in S.C. Columbia The State, September 3.

Bandy, Lee. 2005a. Sanford Run for White House Likely. Columbia The State, February 6.

Bandy, Lee. 2005b. Sanford-for-President Talk Still Has Legs. Columbia The State, September 25.

Barbour, Clay. 2004a. Edwards Keeps Vow to Visit Palmetto State. Charleston The Post and Courier, September 23.

Barbour, Clay. 2004b. Kerry Keeps Cropping Up in Senate Debate. Charleston The Post and Courier, October 19.

Bauerlein, Valerie. 2004. How Edwards Made S.C. Believe. Columbia The State, February 8.

Black, Earl, and Merle Black. 2002. The Rise of Southern Republicans. Cambridge, MA: Harvard University Press.

Broder, David. 2004. S.C. Shows Power of Economy in 2004 Vote. Columbia The State, February 8.

Center for Responsive Politics. 2005. Total Raised and Spent, 2004 Race: South Carolina Senate. (Accessed at www.opensecrets.org/races/summary.asp?ID=SCS1\&Cycle $=$ 2004.)

Frank, John. 2005. Don't Look Now, But Race for White House is On. Charleston The Post and Courier, August 29.

Holland, Jennifer. 2004. Beasley, DeMint Make Final Dash for Votes. Columbia The State, June 22.

Kropf, Schuyler. 2004a. DeMint Leads Senate Race by Wide Margin, Poll Finds. Charleston The Post and Courier, October 3.

Kropf, Schuyler. 2004 b. Anti-gay Rhetoric Not New Among S.C. Republicans. Charleston The Post and Courier, October 10.

Kropf, Schuyler, and James Scott. 2004. Dean, Kerry Spar in S.C.-Exchange on Health Care Issues Enlivens Debate. Charleston The Post and Courier, January 30.

Markoe, Lauren. 2004. GOP's DeMint Starts Afresh. Columbia The State, July 16.

McDonald, Michael P. 2004a. The Numbers Prove that 2004 May Signal More Voter Interest. Milwaukee Journal Sentinel Online, November 27 (accessed at www. jsonline.com/news/editorials/nov04/278724.asp).

McDonald, Michael P. 2004b. Up, Up and Away! Voter Participation in the 2004 Presidential Election. The Forum 2, article 4 (accessed at www.bepress.com/forum/ vol2/iss4/art4/).

Moreland, Laurence W. 1994. South Carolina: Republican Again. In The 1992 Presidential Election in the South: Current Patterns in Southern Party and Electoral Politics, eds. Robert P. Steed, Laurence W. Moreland, and Tod A. Baker. Westport, CT: Praeger

Moreland, Laurence W., and Robert P. Steed. 1997. South Carolina: Elephants Among the Palmettos. In The 1996 Presidential Election in the South: Southern Party Systems in the 1990s, eds. Laurence W. Moreland and Robert P. Steed. Westport, CT: Praeger. 
Moreland, Laurence W., and Robert P. Steed. 2002. South Carolina: Republican, Primarily. In The 2000 Presidential Election in the South: Partisanship and Southern Party Systems in the 21st Century, eds. Robert P. Steed and Laurence W. Moreland. Westport, CT: Praeger.

Moreland, Laurence W., Robert P. Steed, and Tod A. Baker. 1986. South Carolina. In The 1984 Presidential Election in the South: Patterns of Southern Party Politics, eds. Robert P. Steed, Laurence W. Moreland, and Tod A. Baker. New York: Praeger.

Moreland, Laurence W., Robert P. Steed, and Tod A. Baker. 1991. Different Cast, Same Drama in the Palmetto State. In The 1988 Presidential Election in the South: Continuity Amidst Change in Southern Party Politics, eds. Laurence W. Moreland, Robert P. Steed, and Tod A. Baker. New York: Praeger.

National Conference of State Legislatures. 2005. Women in State Legislatures 2005. (Accessed at www.ncsl.org/programs/wln/2004ElectionInfo.htm.)

Rainey, John S. 2005. Lindsey Graham's Fight to Hold the Center Shows Courage. Charleston The Post and Courier, June 29.

Sheinin, Aaron Gould. 2003. Hollings Won't Seek Re-election: “A Time ... To Ho Home." Columbia The State, August 5.

Sheinin, Aaron Gould. 2004. Candidates Jockey for Crucial Second Place. Columbia The State, May 19.

South Carolina Employment Security Commission. 2004. Workforce Trends Newsline (press release of November 19, 2004).

Steed, Robert P. 1997. South Carolina. In State Party Profiles: A 50-State Guide to Development, Organization, and Resources, eds. Andrew M. Appleton and Daniel S. Ward. Washington, DC: Congressional Quarterly Press.

Steed, Robert P., and Laurence W. Moreland. 1999. Ideology, Issues, and the South Carolina Party System, 1980-1996. The American Review of Politics 20:49-74.

Steed, Robert P., and Laurence W. Moreland. 2003. South Carolina: Party Development in the Palmetto State. The American Review of Politics 24:91-108.

Steed, Robert P., and Laurence W. Moreland. 2006, 3rd ed. South Carolina: Change and Continuity in the Palmetto State. In The New Politics of the Old South, eds. Charles S. Bullock III and Mark Rozell. Lanham, MD: Rowman and Littlefield.

Steed, Robert P., Laurence W. Moreland, and Tod A. Baker. 1992. The South Carolina Party System: Toward a Two-Party System. In Government in the Palmetto State: Toward the 21st Century, eds. Luther F. Carter and David S. Mann. Columbia, SC: University of South Carolina Institute of Public Affairs.

Steed, Robert P., Laurence W. Moreland, and Tod A. Baker. 1995a. Party Sorting at the Local Level in South Carolina. The National Political Science Review 5:181-196.

Steed, Robert P., Laurence W. Moreland, and Tod A. Baker. 1995b. South Carolina: Toward a Two-Party System. In Southern State Party Organizations and Activists, eds. Charles D. Hadley and Lewis Bowman. Westport, CT: Praeger.

Talhelm, Jennifer. 2004. Parties Pursue Female Voters in Senate Race. Columbia The State, October 17.

United States Elections Project. 2005. 2004 Voting-Age and Voting-Eligible Population Estimates and Voter Turnout. (Accessed at http://elections.gmu.edu/ Voter_Turnout_2004.htm). 